\title{
The Doctor-Patient Relationship in the Renaissance
}

\author{
Michael Stolberg \\ Institut für Geschichte der Medizin, Universität Würzburg, 97074 Würzburg, \\ Germany \\ michael.stolberg@uni-wuerzburg.de
}

\begin{abstract}
Based on the practice journals, personal notes, and letters of learned physicians from the German speaking regions, this paper seeks to reconstruct the lived reality of the doctor-patient relationship in the sixteenth century. Even many affluent and educated patients were quick to consult another practitioner when they were not satisfied, and the physicians resorted to various strategies to win and maintain the patient's trust. These included preferring or outright inventing a diagnosis the patient could not prove wrong and deliberately exaggerating the severity of the disease so the physicians would gain all the more praise (and money) when the patient got better. On the positive side, the physicians respected their patients' desire for certain medicines and their dislike of others, and went to great lengths to provide them with an explanation of what was happening inside their bodies that made sense to them and matched their personal bodily experience.
\end{abstract}

\section{Keywords}

doctor-patient relationship - consultation - Renaissance medicine - Georg Handsch - Germany

\section{Introduction}

We know very little about the doctor-patient relationship in the Renaissance. In marked contrast to the seventeenth and eighteenth centuries, ${ }^{1}$ the literature

1 In work on the history of medicine from the patient's perspective in the seventeenth and eighteenth centuries, the doctor-patient relationship is frequently described, implicitly 
is scarce and mostly limited to vague generalizations. ${ }^{2}$ This is due above all to a lack of suitable sources. Historians have so far relied primarily on prescriptive, deontological texts such as Gabriele Zerbi's De cautelis medicorum or Leonardo Botalli's De officio medici. ${ }^{3}$ Like their medieval predecessors, ${ }^{4}$ the authors of these deontological texts provide valuable insights into how learned physicians envisaged an ideal, successful physician-patient relationship that would allow the physician to assert his authority and - not to be neglected - the promotion of his financial interests. Reading between the lines, some of the advice offers glimpses of areas of conflict, for example, when authors recommended that the physician ask for his fees while the patient was still sick. Ultimately, however, such deontological works tell us very little about the lived reality of the doctor-patient encounter in the Renaissance, about how physicians and patients interacted and related to each other in everyday medical practice. ${ }^{5}$

or explicitly; see among others, Roy Porter, ed., Patients and Practitioners: Lay Perceptions of Medicine in Pre-Industrial Society (Cambridge, 1985); Lucinda McCray Beier, Sufferers \& Healers: The Experience of Illness in Seventeenth-Century England (London-New York, 1987); Roy and Dorothy Porter, Patient's Progress: Doctors and Doctoring in Eighteenth-Century England (Cambridge, 1989); Barbara Duden, The Woman Beneath the Skin: A Doctor's Patients in Eighteenth-Century Germany (Cambridge, MA, 1991); Michael Stolberg, Experiencing Illness and the Sick Body in Early Modern Europe (London, 2011); Olivia Weisser, Ill composed: Sickness, Gender, and Belief in Early Modern England (New York-London, 2015).

2 Pedro Laín Entralgo, La relacion medico-enfermo: Historia y teoria (Madrid, 1964), 178-96; Claudia Pancino, "Doctor and Patient in the Modern Age: Words, Gazes and Gestures," in Maria Malatesta, ed., Doctors and Patients: History, Representation, Communication from Antiquity to the Present (San Francisco, CA, 2015), 81-107. Some aspects of the doctor-patient relationship in the Renaissance, such as truth-telling and female modesty, are also dealt with, again based on prescriptive, deontological sources, in work on the history of medical ethics; see, e.g., Winfried Schleiner, Medical Ethics in the Renaissance (Washington, D.C., 1995); Klaus Bergdolt, Das Gewissen der Medizin. Ärztliche Moral von der Antike bis heute (Munich, 2004), $145^{-55}$.

3 Salvatore de Renzi, ed., Collectio Salernitana II (Naples, 1854), 74-80 and ibid., V, 333-350; Gabriele Zerbi, Opus perutile de cautelis medicorum (Venice, after 1494); Leonardo Botalli, Commentarioli duo, alter de medici, alter de aegroti munere (Lyon, 1565); cf. Michael R. McVaugh, "Bedside Manners in the Middle Ages," Bulletin of the History of Medicine, 71 (1997), 201-233; Jana Madlen Schütte, Medizin im Konflikt: Fakultäten, Märkte und Experten in deutschen Universitätsstädten des 14. bis 16. Jahrhunderts (Leiden, 2017), 76-81; Barbara Elkeles, "Arzt und Patient in der medizinischen Standesliteratur der Frühen Neuzeit," in Udo Benzenhöfer and Wilhelm Kühlmann, eds., Heilkunde und Krankheitserfahrung in der Frühen Neuzeit (Tübingen, 1992), 131-143.

4 Bergdolt, Gewissen, 82-92.

5 In her study of physicians in fifteenth-century Florence, Katy Park has fruitfully complemented her reading of Zerbi with evidence from patients' account books and ricordanze; see Katherine Park, Doctors and Medicine in Early Renaissance Florence (Princeton, NJ, 1985), 109-117. 
In this paper, I will take a different approach. Focussing on the Germanspeaking world, my analysis will draw largely on unpublished manuscript sources that reflect the day-to-day interactions between patients and physicians in a much more immediate and nuanced manner. These are, in particular, practice journals and physicians' personal notebooks. Practice journals, in which physicians recorded (more or less) chronologically the patients they saw, have unfortunately rarely survived from this period. The entries in the two hitherto-known sixteenth-century journals from Germany - those of Johannes Magenbuch and Georg Palm in Nuremberg - are both largely limited to the names of the patients and the dates of the consultations. ${ }^{6}$ Two other recently discovered practice journals now make it possible to arrive at a fuller picture, namely the practice journal of the Prague physician Ulrich Lehner for the years $1547-1550^{7}$ and, above all, the Ratiocinium praxeos medicae of Hiob Finzel, three heavy folio volumes that cover almost 25 years of medical practice in Weimar, Eisenach and Zwickau, from 1565 until his death in $1589 .{ }^{8}$ It is the most extensive and complete practice journal that is so far known to have survived from any doctor medicinae in sixteenth-century Europe. ${ }^{9}$

Practice journals are of unique value as a source for the kinds of patients and illnesses the physicians saw and sometimes, as in Finzel's case, also contain important information on economic aspects, on the frequency of visits, and the quality of the doctor-patient-relationship. The value of physicians' personal notebooks, by contrast, lies in their sometimes quite detailed descriptions of many different patients and cases, and of different types of encounters. In what follows, I will draw primarily on the notes of the Bohemian physician Georg Handsch, who studied medicine in Padua, received his doctoral degree

6 Stadtbibliothek Nürnberg, Ms Cent. V, 1ob and Germanisches Nationalmuseum, Nürnberg, Hs 100.822 (Georg Palm); Universitätsbibliothek Heidelberg, Cpl 1895-1 (Johannes Magenbuch); cf. Peter Assion and Joachim Telle, "Der Nürnberger Stadtarzt Johannes Magenbuch. Zu Leben und Werk eines Mediziners der Reformationszeit," Sudhoffs Archiv, 56 (1972), 353-421; Klaus G. König, Der Nürnberger Stadtarzt Dr. Georg Palma (1543-1591) (Stuttgart, 1961).

7 Österreichische Nationalbibliothek, Vienna (hereafter: ÖNB), Cod. 11006 and Cod. 11247 are copies of Lehner's casebooks with additional entries by Georg Handsch.

8 Ratschulbibliothek Zwickau, Ms. QQQQ1, Ms. QQQQ1a and Ms. QQQQ1b; on Finzel's biography see Björn Aewerdieck, Register zu den Wunderzeichenbüchern Job Fincels (Frankfurt am Main, 2010), 10-21 and 277-285; Michael Stolberg, "A Sixteenth-Century Physician and His Patients: The Practice Journal of Hiob Finzel, 1565-1589," Social History of Medicine, 32 (2019), 221-240.

9 The journals of Simon Forman and John Napier, with many thousands of entries on their astrological practice, are even more extensive but neither of them was a doctor medicinae. For a detailed analysis, see Ronald C. Sawyer, Patients, Healers, and Disease in the Southeast Midlands, 1587-1634 (PhD thesis, University of Wisconsin, 1986); the casebooks have been the object of a major recent digital project, directed by Lauren Kassell in Cambridge (see https:// casebooks.lib.cam.ac.uk, last accessed 8 January 2021). 
in Ferrara in 1553, and then worked as a physician first in Prague and later in Innsbruck. Handsch left a series of notebooks with altogether more than 4,ooo pages of personal notes, in Latin, mostly on numerous patients he, his teachers, and a range of other physicians with whom he was acquainted or collaborated, had in their care. ${ }^{10}$ It is a unique source, all the more so since Handsch was neither a famous physician nor had any intention of publishing his notes. ${ }^{11}$ With an openness that would be unthinkable in printed publications, he frequently even highlighted the mistakes and errors he and other physicians made in their dealings and communication with the patients. Handsch also documented extensively how the patients and their families reacted to the physicians, their diagnoses and their prescriptions. He frequently even quoted verbatim how the physicians explained the illness and their prescriptions, and sometimes also how the patients described their illness and responded to the physicians' questions.

As rich as they are, compared with the deontological writings upon which historians have so far largely relied, these sources inevitably give an indirect reflection only of the physicians' point of view. Insights into the ways in which patients (presumably) lived and experienced the doctor-patient-relationship can be derived only through the doctors' descriptions of their interactions with the patients, and the context of medical practice in general. Occasionally, I will quote patient letters, personal diaries and similar sources that historians have successfully used to reconstruct the patients' experience of illness and the doctor-patient relationship in the seventeenth and eighteenth centuries, especially in the English context. ${ }^{12}$ Unfortunately, they are much scarcer for

10 ÖNB, Codd. 955o, 9607, 9650 9666, 9671, 9821, 11006, 11130, 11141-3, 11153, 11158, 11183, 11200, 11204-11208, 11210, 11226, 11231, 11238-40 and 11251; cf. Michael Stolberg, "Empiricism in Sixteenth-Century Medical Practice: The Notebooks of Georg Handsch," Early Science and Medicine, 18 (2013), 487-516. For biographical information, see Leopold Senfelder, "Georg Handsch von Limus. Lebensbild eines Arztes aus dem xvi. Jahrhundert," Wiener klinische Rundschau (1901), 495-499, 514-516, 533-535; Josef Smolka and Marta Vaculínová, "Renesanční lékař Georg Handsch (1529-1578)," DVT - Dějiny věd a techniky, 43 (2010), 1-26; Michael Stolberg, Gelehrte Medizin und ärztlicher Alltag in der Renaissance (Berlin, 2021) draws extensively on Handsch's notebooks.

11 The reason for taking all these notes on different cases and on what he learnt about medical matters from colleagues, patients, friends and members of his own family was that he apparently hoped they would help him become a skilful practitioner. As it turned out, however, he was never particularly successful. Competition in Prague was steep. It was probably only the support of one of his mentors, the famous Pietro Andrea Mattioli, that eventually enabled him to obtain a (rather modestly remunerated) position as one of the personal physicians to Archduke Ferdinand II, in the late 156os. He moved with the Archduke to Innsbruck and also treated some patients outside the court. 
the time before 1600 and even more rarely go into any detail as to the actual interactions with the physician.

\section{Patients}

Any account of the physician-patient relationship in the Renaissance has to start with a simple but important observation: There was not one 'typical' physician-patient relationship, not one standardized way in which physicians and patients interacted. The doctor-patient relationship varied widely in its intensity and quality, depending, in particular, also on the social standing of the patient.

This claim may at first glance seem surprising. Historians have traditionally assumed that learned physicians in the early modern period treated almost exclusively a small and relatively homogenous elite of wealthy and educated upper-class patients. ${ }^{13}$ Over the last decades, scholars have cast considerable doubts on this idea, however, backed up more recently by hard data from a systematic analysis of physicians' practice journals for the time after $1650 .{ }^{14}$ Hiob Finzel's Ratiocinium yields very similar findings for the preceding period. His data is particularly revealing because he was, to all appearances, a fairly typical representative of a rapidly growing group of medical practitioners. He served as a town physician, as did most physicians in the Holy Roman Empire, at least for parts of their professional career. From the late Middle Ages, town authorities north of the Alps increasingly adopted the Italian model of the medico condotto. ${ }^{15}$ In order to assure that the services of an academic physician were always available, they employed a learned physician - and sometimes more than one - for an (often quite modest) annual salary. In return, the physician had to reside in the town and was usually not allowed to leave the town overnight without the explicit permission of the town authorities. The contracts for

13 See, e.g., the influential study by Nicholas D. Jewson, "Medical Knowledge and the Patronage System in 18th Century England," Sociology, 8 (1974), 369-385.

14 Park, Doctors, 113; Laurence W.B. Brockliss and Colin Jones, The Medical World of Early Modern France (Oxford, 1997), 284-296; Philip Klaas, Hubert Steinke and Alois Unterkircher, "Daily Business: The Organization and Finances of Doctors' Practices," in Martin Dinges, Kay Peter Jankrift, Sabine Schlegelmilch and Michael Stolberg, eds., Medical Practice, 1600-19oo. Physicians and Their Patients (Leiden, 2016), 71-98, here 91-92.

15 Cf. Richard Palmer, "Physicians and the State in Post-Medieval Italy," in Andrew W. Russell, ed., The Town and State Physician in Europe from the Middle Ages to the Enlightenment (Wolfenbüttel, 1981), 47-61; Park, Doctors, 87-94. 
these German town physicians also routinely stipulated that they had to offer medical care to the rich and poor alike, and frequently specified that the physician had to adapt his fees to the financial means of his patients. Sometimes the town authorities even reserved the right to set the fee when the physician and his patient could not agree.

Finzel's journal suggests that this policy worked remarkably well. Since he used his practice journal as a means to calculate his total earnings at the end of each year, we can safely assume that he documented at least almost all the patients he saw. ${ }^{16}$ Between January 1572 and December 1588, Finzel recorded a total of about 6,500 individual patients. For about 3,000 of them he added some information on the social or professional background of the patient (or his or her father or the family breadwinner). Only about 8 per cent of these patients came from the local or regional aristocracy. The large majority belonged to the urban upper and middle classes. We find members of the city council and city officials but also teachers and clergymen - 170 patients alone came from pastors' households - and dozens of craftsmen such as millers, coachmen, blacksmiths and nailsmiths, dyers, shoemakers, potters, tailors, bookbinders, candlemakers and furriers, plus a number of innkeepers and musicians. Even more strikingly, there were 733 patients whom Finzel simply called "country folk" ("rusticus", "rustica"), most of whom presumably made their living as farmers or farmhands. Finzel's figures for the fees he received from his patients underline that even families with very modest financial means could indeed afford his services. While some of his more affluent patients rewarded him with several gulden, the large majority only paid one, two or three groschen per visit - the price of a dozen or so eggs or of a chicken.

As we learn from Handsch's notebooks, even renowned court physicians like Andrea Gallo and Pietro Andrea Mattioli in Prague not only provided medical care to members of the Habsburg family and of the nobility but also to patients from the middling and lower ranks. Some of these were cooks, kitchen hands and other servants who were employed by the court or the nobility who presumably paid for their treatment. ${ }^{17}$ The physicians were also consulted by artisans and students from the city, and rural folks from the surrounding countryside. In his practice journal, Handsch's first medical teacher in Prague,

16 Ratschulbibliothek Zwickau, Ms. QQQQ 1, Ms. QQQQ 1a and Ms. QQQQ 1b; see Stolberg, "Sixteenth-Century Physician," for a detailed analysis and a summary of the methodological problems, e.g., in identifying two consultations for one and the same patient referred to by Finzel in different ways. My thanks to Hannes Langrieger for his invaluable support in performing this statistical analysis.

17 Finzel documented the same practice (e.g., Ratschulbibliothek Zwickau, Ms. QQQQ1a, 47). 
magister Ulrich Lehner, explicitly assigned his patients to three groups: the barones, the nobiles and the plebeios. The latter included a fisherman, a butcher, a goldsmith, an organ player and various merchants. Georg Palm and Johannes Magenbuch, who were well-known physicians in one of the most prosperous cities in sixteenth-century Europe, predominantly treated members of the rich patrician families in Nuremberg but also some ordinary citizens.

In a highly hierarchical society like that of Renaissance Germany, differences in upbringing and social status presumably had a powerful impact on the doctor-patient relationship. On the one hand, establishing a fairly personal relationship would have been easier, when physician and patient shared a similar cultural background and moved in the same social circles. Most learned physicians in the sixteenth century had a thorough humanistic education, first in Latin school and then in the arts faculty, and many of them came from families who belonged to the educated urban elites. It was not uncommon, in fact, that physicians gave medical advice to patients who were - or had become personal friends. Patients from the nobility enjoyed a higher social status than most physicians but humanist culture had a powerful and pervasive impact on the aristocracy, too. At the other end of the spectrum, by contrast, the urban lower classes and, above all, the numerous country people had a very different cultural background. They were not acquainted with Latin and the rich classical tradition. Indeed, they were often illiterate.

It is difficult to pin down the precise impact of such differences in social rank and cultural background, but Finzel's practice journal certainly suggests that such differences had a very concrete effect on the doctor-patient relationship. Compared with entries on patients from the educated classes, those for many urban lower class and rural patients often suggest a quite literally anonymous relationship: Finzel frequently did not even record their names but only used a generic term like "rusticus" or "rustica" or, at best, "man from" or "woman from" followed by the place of residence. Likewise, Handsch sometimes only recorded the profession, when he wrote about patients he or one of his colleagues treated. It is also revealing, in this context, that at one point he reminded himself that he should test the effects of an opium preparation opium was known to be dangerous and difficult to dose - on "some man from the country-side". 18

Differences in social rank were not only important because they indicated a different cultural background. Entries by Finzel and Handsch on individual patients also suggest, each in their own way, that patients from the lower ranks were less likely to consult a learned physician repeatedly or indeed over

ÖNB, Cod. 11205, 223r: "His ergo positis, omnino experiar in aliquo rustico." 
an extended period of time. One of the most striking findings that emerges from Finzel's journal is the large number of different patients and the very small number of consultations, on average, per individual patient. In seventeen years of practice in Zwickau, Finzel saw about 6,500 different patients from the town and the surrounding countryside - the population of Zwickau was less than 10,000. When we compare this figure with the total of not even 9, ooo consultations that Finzel recorded in the same period, it becomes clear, that the majority of Finzel's patients consulted him once only. Presumably, many patients simply gave him a try. If they got better they did not need to come back, and if their health did not improve they might consult another physician, a barber-surgeon or a lay healer or might have used domestic medicines. Even wealthy craftsmen, merchants and clergymen, teachers and other patients from the city's educated middle classes were often content with one, two or at most three consultations, and only exceptionally returned to him when they later fell sick again. On the other hand, there was a small number of mostly educated middle- and upper-class and aristocratic patients who sought Finzel's advice quite frequently and assiduously. Finzel recorded up to 200 visits to patients from one and the same family.

Handsch's notes on the patients he and his colleagues treated in Prague and Innsbruck do not permit a statistical analysis because he did not take notes on every single patient, let alone on every single visit. In his notes, too, some patients are mentioned only once but, much more frequently than in Finzel's journal, Handsch's notes indicate a cure which lasted for several days or weeks and entailed a series of daily visits to the patient's home and sometimes even two on the same day. This may reflect, in part at least, the fact that Handsch and his colleagues treated predominantly (though not exclusively) patients that belonged to the households of the upper classes. Ego-documents of upper-class patients in the sixteenth century, such as the diary of Hermann Weinsberg (1518-1597) in Cologne, also show that they preferred to call the same doctor whenever someone in the family was ill. ${ }^{19}$

In sum, my sources strongly suggest that an ongoing, lasting physician-patient relationship and the familiarity and trust it could foster were the exception at the time rather than the rule. In qualitative and even in financial terms, however, a smaller group of patients that consulted the physician more frequently played a crucial role in the practice of learned physicians, even in that of a rather ordinary town-physician like Finzel. Some patients and indeed entire families entrusted their health to one physician over extended periods

19 Hermann Weinsberg, Das Buch Weinsberg. Kölner Denkwürdigkeiten aus dem 16. Jahrhundert, 5 vols. (Düsseldorf, 2000); see also Brockliss and Jones, Medical World, 301 and 305-306. 
of time. Several families even accorded a regular salary to Finzel for his services: Wolf von Weisbach and Heinrich von Enda paid him seven and ten taler respectively as a "half-year salary" and from Jörg Albrecht von Witzleben he even received 30 gulden as an "annual salary". ${ }^{20}$

The physician-patient relationship, it should be added, was, according to my sources, more often than not a relationship between two men. The ratio between consultations for male and for female patients in surviving practice journals from that period ranges from about 57 per cent against 43 per cent in Finzel's practice; 63 per cent against 37 per cent in that of Palm in Nuremberg; and up to 71 per cent against 29 per cent in Peter Kirsten's prescription diary from early seventeenth-century Breslau. ${ }^{21}$

Across times and cultures, the quality and intimacy of the physician-patient relationship tends to depend not only on the social and cultural background of the patients but also on the circumstances, on where the encounter takes place, on how much time the practitioner can devote to each patient and on who else is present. Historians of early modern medicine have rightly underlined the importance of house calls. The patient's home was not the only site of the medical encounter, however. It could take place in different settings and take different forms.

Sometimes the physician and his patient did not meet in person at all. Among the upper classes, consulting by letter was common practice by the late sixteenth century. The patient, his or her family, or a local physician, described the disease to a distant physician who would express his judgment and propose a suitable course of treatment. Sometimes, they sent a sample of the patient's urine with the letter. One of the great advantages of uroscopy, the principal diagnostic method at the time, was in fact that the practitioner did not need to see the patient in person. A messenger could bring the patient's urine or indeed that of several different patients to the physician's house. In a letter he sent from Schlettstatt in 1554, Michael Bäris, for example, prided himself of his

\footnotetext{
20 Ratschulbibliothek Zwickau, Ms. QQQQ1, 39 and Ms. QQQQ1a, 42 and 385.

21 Stolberg, "Sixteenth-Century Physician"; Franziska Ofenhitzer, Praxisalltag in der Frühen Neuzeit. Das Rezeptdiarium (1612-1616) von Petrus Kirstenius aus Breslau (Med. diss., Würzburg, 2015). By contrast, Wendy Churchill, in her analysis of seventeenth- and eighteenth-century casebooks from Britain, has found a majority of female patients; see Wendy D. Churchill, Female Patients in Early Modern Britain: Gender, Diagnosis, and Treatment (Farnham, 2012), $43-54$.
} 
successful practice covering an area three miles around. The day before he had not found the time to eat until late, he added, because he had to examine the urine of fifteen different patients. ${ }^{22}$

While regular office hours during which the patients could come to see the physician are a more recent development, ${ }^{23}$ the importance of another site of medical practice must not be underestimated either: the physician's own home. Finzel's journal does not specify where he saw his patients but especially in the case of farmers and other country folk it would seem very unlikely that he travelled to their village, just for a couple of groschen. If they did not just send samples of urine they presumably came to see Finzel in Zwickau. And even patients who lived in the same town as the physician did not necessarily request his visit but went and saw the physician in his own home instead. ${ }^{24}$ As a young physician, when he still lived in his father's house in Basel, Felix Platter, according to his own account, "interrogated" his patients in his chamber or study or, in the winter, in the "lower hall", which, it seems, could be heated. ${ }^{25}$ In 1573, the Esslingen town physician Tobias Baltz demanded a more suitable residence, complaining that at present those seeking his medical advice had to climb up to the upper parlour to see him and then descend again. Baltz's letter indicates that some doctors even put up patients in their homes, for the duration of their treatment. For this purpose, Baltz complained, his current official residence was too small. ${ }^{26}$

The evidence is only anecdotal at this point, but it does thus suggest that we must not underestimate the degree to which learned physicians in the sixteenth century received patients in their own houses. Especially the more affluent patients, however, with whom the physician was most likely to establish a continuous, longstanding relationship usually seem to have called the physician. They expected him to come and see them, usually in their sick chamber, the "hypocaustum," as Handsch often called it, presumably because it could be heated. ${ }^{27}$

22 Letter to Bonifaz Amerbach, 10 October 1554, in Beat Rudolf Jenny, ed., Die Amerbachkorrespondenz, Vol. 9.2 (Basel, 1983), 403-404; summary online at www. aerztebriefe.de/id/oooo8204, last accessed 8 January 2021.

23 Ingrid Vieler, Die deutsche Arztpraxis Im 19. Jahrhundert (Med. diss., Mainz, 1958).

24 For the time from the mid-seventeenth-century onwards, see also Klaas, Steinke and Unterkircher, "Daily Business," 73-75.

25 Felix Platter, Tagebuch (Lebensbeschreibung) $1536-1567$, ed. Valentin Lötscher (Basel, 1976).

26 Letter from Tobias Baltz to the town council of Esslingen, 16 December 1573, www. aerztebriefe.de/id/ooo3o643, last accessed 8 January 2021.

27 ÖNB, Cod. $11183,242 v$; the term derives from the ancient Roman technique of heating rooms from rooms or spaces underneath. 
In many respects, such visits in the patient's own home offered better conditions for a more personal relationship than is usual between a doctor and patient today. In their letters, physicians sometimes complained about being overburdened with patients but, except for times of epidemics, this usually must be taken with a grain of salt. Finzel's journal, like those of Magenbuch and Palm in Nuremberg - and, in the early seventeenth century, the prescription diary of Peter Kirsten in Breslau - all indicate that the physician only saw, at best, two or three patients a day, on average. In other words, there was time for a good conversation, for detailed questions to the patient, for explanations on the part of the physician. The physician might even stay for dinner or, in the case of high-ranking patients, remain for several days in a row, ready to assist the patient even in the middle of the night, as Handsch did with some patients who lived in the countryside. Some court physicians even lived at court and might have been expected to accompany the ruler and his family wherever they went. ${ }^{28}$

Handsch's notes also underline another important difference with the modern idea of a 'personal' physician-patient relationship, a difference which work on the social history of early modern medicine has pointed out for some time. ${ }^{29}$ The physician was often not alone with his patient. Not only did high-ranking patients frequently call more than one physician who would then have to agree on the diagnosis and the most suitable course of treatment. Even among ordinary folks, members of the family, servants and even neighbours and friends often assembled in the sick chamber, curious to hear what the physician had to say. It was therefore frequently this extended audience to which the physician had to play, which he had to convince of his diagnostic and therapeutic skills in general, and of the validity of his judgement in the case in question. We can only speculate on the effects these gatherings had on the patients themselves. It may have comforted them and given them strength vis-à-vis the physician, but it may also, at times, have increased the pressure on them to heed his dietetic advice and to follow his prescriptions.

28 On court physicians, see Vivian Nutton, ed., Medicine at the Courts of Europe (1500-1837) (London, 199o); Elisa Andretta and Marilyn Nicoud, eds., Etre médecin à la cour (Italie, France, Espagne, XIIIe - XVIIIe siècle) (Florence, 2013); Elena Taddei and Marina Hilber, eds., In fürstlicher Nähe. Ärzte bei Hof (1500-1850) (Innsbruck, forthcoming).

29 E.g., Ronald C. Sawyer, "Friends or Foes? Doctors and Their Patients in Early Modern England," in Yosio Kawakita, Shizu Sakai and Yasuo Otsuka, eds., History of the Doctor-Patient Relationship (Tokyo-Brentwood, 1995), 31-53, here, 36-39. 
Deontological works traditionally outlined a set of rules on how the physician should behave towards the patients and other members of the household. They recommended, in particular, that the physician cultivate an air of gravity and authority and that he should dress appropriately, with care but without excessive luxury. In his notebooks, young Handsch repeatedly reminded himself of these norms. "Do not make yourself unworthy. Retain authority," was one of his mottos. ${ }^{30}$ Modesty and steadfastness were essential, he noted. And, it must be remembered, since Handsch in this respect found himself repeatedly reproached: the physician should not get drunk. ${ }^{31}$

In important respects, Handsch's notes have a somewhat different ring, however, compared with published deontological writing. He underlined much more the emotional aspects, the need to be friendly and empathic, as we would say today. To win the favour and trust of his patients, he reminded himself, the physician had to show "humanity and devotion". ${ }^{22}$ He had to take his time, make it clear that he took the patients and their complaints seriously and listen to their stories "patiently and attentively". ${ }^{33}$ If he did so, the patients would say "he has been faithful to me and has applied all his diligence". ${ }^{34}$ Handsch's colleague Jacobus Camenicenus, he learnt, had many patients, because he was "blandiloquus," i.e., he knew how to please and flatter his patients. ${ }^{35}$ By contrast, people called another colleague of Handsch's an "oxen" because he squeezed the patient's wrist so hard when he felt for the pulse that he left bluish bruises. ${ }^{36}$ Handsch even deemed small gestures worthy of note, such as reaching out a hand to the sick person when he said goodbye. ${ }^{37}$

As his sometimes quite detailed descriptions of encounters with individual patients show, Handsch and his colleagues practiced to a large degree a 'talking medicine'. The physicians might not go through the whole list of questions that contemporary advice on how to interrogate the patient recommended ${ }^{38}$ but they enquired in considerable detail into the patient's history and current

30 ÖNB, Cod. 11240, 2 r.

31 ÖNB, Cod. 11205, 56ov.

32 ÖNB, Cod. 11206, 178v: "Medicum non tantum decet experientia, sed humanitas \& affabilitas".

33 ÖNB, Cod. 11200, 56v.

34 ÖNB, Cod. 11205, 69ov.

35 Ibid., $129 \mathrm{v}$.

36 Ibid., 237r and 272r.

37 Ibid., 513r.

38 E.g., Girolamo Capivaccio, "De modo interrogandi aegros," in idem, Opera omnia, ed. Johann Hartmann Beyer (Frankfurt, 16o3), 236-237. 
complaints and entered into a veritable dialogue with the patient. They had to. From the physicians' perspective, the diagnosis and the choice of treatment depended crucially on what the patients and sometimes also their families and other bystanders had to say about the history of the illness and the current complaints.

For the sake of their health, the patients, in turn, were even ready to talk about things that were commonly considered embarrassing or shameful. Menstruation was one of them. For example, Handsch mentioned a woman who did not want to admit, at first, that she did not have her monthlies. ${ }^{39}$ With others he felt he could not ask about menstruation because the husband was present. ${ }^{40}$ However, the regular monthly cleansing of the female body was widely regarded as indispensable for a woman's health. Numerous other entries in Handsch's notebooks provide ample evidence that the doctors often did talk about menstruation with their patients and that many women actively sought advice on their own initiative because of a disturbed menstrual cycle.

An even more powerful source of shame and embarrassment were the 'whites' and other unpleasant genital discharges. According to Handsch, it was a common complaint which many women preferred not to address, because they were "ashamed," or to which they only "confessed," when the physician explicitly asked about them. ${ }^{41}$ Yet, in the end, even women who kept their whites secret, at first, sought help, for example, because they felt weakened by the constant loss of matter. ${ }^{42}$

Male patients, too, overcame their shame when necessary. Some men with gonorrhoea or syphilis - the so-called French disease - for example, "confessed", as Handsch put it, that they had seen prostitutes. ${ }^{43}$ Others even consulted the physician for what was probably the most shameful complaint a male patient could present with at the time, sexual impotence. If he was rumoured to be impotent, a man's honour was in serious danger; in the worst cases, the scandal of a public trial for impotence could follow and his marriage might be declared invalid. ${ }^{44}$ The hope of these men that the physician could help them, and their trust that he would not betray their confidence, was evidently stronger than their fear that he might pass the information on to others. ${ }^{45}$

39 ÖNB, Cod. 11206, 35v.

40 ÖNB, Cod. 11183, 10v, "propter praesentiam mariti"; similarly, ÖNB, Cod. 11207, 111r, "propter praesentiam viri".

41 ÖNB, Cod. 11183, 46or; ÖNB, Cod. 11206, 33r; ÖNB, Cod. 11226, 107v.

42 ÖNB, Cod. 11205, 528 r.

43 ÖNB, Cod. 11183, 177r.

44 Pierre Darmon, Trial by Impotence: Virility and Marriage in Pre-Revolutionary France (London, 1985).

ÖNB, Cod. $11183,87 \mathrm{r}, 158 \mathrm{v}, 185 \mathrm{r}$ and $222 \mathrm{v}$. 
Intimacy in the physician-patient encounter was not limited to words. It was frequently accompanied by a remarkable measure of physical closeness. For a long time, medical historians have claimed that early modern physicians hardly touched their patients at all. ${ }^{46}$ Yet when we look at sources that reflect actual medical practice rather than at general printed textbooks, it quickly becomes clear that learned physicians, as early as in the sixteenth century, often if not routinely touched their patients. Not only did they feel the pulse (which was, after uroscopy, the major diagnostic method at the time) and the tongue (to see whether it was hard or dry); when they suspected that the pathological process or the morbid matter in question was located in the abdominal area they also palpated the abdomen with their own hands. In fact, performing a physical, manual examination of the abdomen was the "custom" ("mos est") as Handsch put it and his notes as well as published medical observations offer numerous examples for this practice. ${ }^{47}$

With female patients, shame sometimes proved an insuperable obstacle. Handsch described his encounter with a young female patient whom he neither dared ask about her menstruation and her stools nor touch her upper abdomen "propter verecundiam". Young unmarried woman were particularly embarrassed, he added, when the physician himself was also young, as Handsch was at the time. ${ }^{48}$ On the other hand, Handsch mentioned female patients who even bared their private parts to the physician and allowed him to touch them and he described in considerable detail how he sought to inject, with his own hands, some warm wine into a patient's womb, by means of a catheter. The woman had lain on a table, he added, with her legs spread apart. ${ }^{49}$

\section{$5 \quad$ Winning Trust (by all Means)}

Good bedside manners were important, certainly, when physicians were dealing with the upper-class patients to whom many of them owed much of their income. Ultimately, patients wanted to be cured, however.

46 See, e.g., Sawyer, "Friends or Foes?" 39; Roy Porter, "The Rise of Physical Examination" in W. F. Bynum and Roy Porter, eds., Medicine and the Five Senses (Cambridge, 2004), 179-197.

47 ÖNB, Cod. 11183, 125v; Michael Stolberg, "Examining the Body (c. 1500-1750)," in Sarah Toulalan and Kate Fisher, eds., The Routledge History of Sex and the Body, 1500 to the Present (Oxford, 2013), 91-105.

48 ÖNB, Cod. 11207, 210r.

49 ÖNB, Cod. 11183, 7r-v; for similar findings in seventeenth- and eighteenth-century Britain, though mostly relating to surgeons, see Olivia Weisser, "Boils, Pushes and Wheals: Reading Bumps on the Body in Early Modern England," Social History of Medicine, 22 (2009), 321-339; 
The first step was diagnosis. The patients and their families were not satisfied with just some abstract Latin disease name. "They always want to know where the illness comes from," Handsch noted..$^{50}$ They expected the physician to provide them with a precise account of what was going on inside the patient's body and of how he intended to fix it. This explanation had to make sense within the framework of their own medical ideas and it had to correspond to the patient's subjective perception of his or her diseased body. ${ }^{51}$

The best evidence of the great importance the patients - and, as a result, also the learned physicians - attributed to a plausible, convincing diagnosis comes from the hundreds of entries in which Handsch recorded, often verbatim and in German, the explanations the physicians could or did use for this purpose. ${ }^{52}$ Sometimes, Handsch added a note on how the patients reacted. When they came back with the money for the medicines Handsch had recommended, this reassured him that he had used the right words..$^{53}$ Occasionally he even commented a 'successful' explanation with a "placuit" or "non displicuit" in the margin; since the patients had been pleased with how he had worded his explanation, he could hope to achieve a similar effect using the same expressions with future patients. ${ }^{54}$

With his diagnosis, the physician could often remain on safe ground. When he attributed a patient's illness, for example, to an accumulation of cold, mucous matter in the stomach and an obstruction of the mesenterial veins that were thought to transmit the chymus to the liver to be transformed into blood - this was a very common diagnosis - the patient had no means to disprove his diagnosis. Likewise, when he diagnosed a "secret fever," "inner measles" or some other pathological process inside the body, ${ }^{55}$ he could hardly be proven wrong. When the patient developed a full-blown fever or the typical measles rash, he would be praised for his diagnostic acumen ("bene dixisti"), Handsch noted. If not, there was a simple explanation: the fever or the measles had remained inside and never manifested themselves to the senses. ${ }^{56}$

on the potential sexual undertones of physicians' visits to female patients, see Sarah-Maria Schober, Gesellschaft im Exzess. Mediziner in Basel um 1600 (Frankfurt, 2019), 190-194.

$50 \quad$ ÖNB, Cod. 11205, 428r, "semper volunt scire unde morbus."

51 See also Roger K. French, Medicine Before Science: The Rational and Learned Doctor from the Middle Ages to the Enlightenment (Cambridge, 2003), 118-122.

$5^{2}$ Michael Stolberg, "You Have No Good Blood in Your Body': Oral Communication in Sixteenth-Century Physicians' Medical Practice," Medical History, 59 (2015), 63-82.

53 ÖNB, Cod. 11206, 17r, 35v and 39v.

54 E.g., ibid., 39v and 4or.

55 Ibid., $25 \mathrm{v}$.

$5^{6}$ ÖNB, Cod. 11205, 213v. 
The big challenge in the diagnostic realm was uroscopy, however, especially when the patient, as was common practice, only sent their urine with little or no further information about their state and their complaints. Based on a careful examination of the urine and on whatever the messenger could and was prepared to add, the physician was expected to arrive at a precise diagnosis and propose a treatment. People might even demand that the physician make pronouncements on the sex and age of a patient, just from looking at the urine; or that he should be able to confirm or exclude a pregnancy. Learned medical writers harshly criticized this practice. Diagnosing diseases just from a urine sample, without seeing the patient in person, was very unreliable, they argued. With drastic words, they warned that physicians could make embarrassing errors that seriously damaged their authority. How easily might they diagnose a fatal disease and see the patient recover to perfect health instead! How embarrassing was it when the physician excluded that a woman was pregnant, only to hear a few months later that she had given birth! Even worse, diagnosis from the urine only left the physician at the mercy of people who might test and trick him, for example, by sending the urine of a woman or indeed that of a cow, pretending it was that of a man! ${ }^{57}$

The physicians faced a serious problem, however. Countless barber-surgeons and lay healers routinely diagnosed and treated patients, based just on an examination of the urine. The patients, in turn, were frequently satisfied with their judgment, all the more so because they often eventually got better under the treatment the uroscopist recommended. The learned uroskeptics sought to expose the fraudulent tricks of these popular uroscopists who slyly elicited crucial information from the messengers, coaxing them, for example, into referring to the patient as "he" or "she," or who pretended to be absent, only to listen in hiding to how the messenger responded to the questions put to them by the uroscopist's wife. Yet, ultimately, the physicians had little choice. If they did not want to risk looking incompetent and losing patients, they had to go along with this practice of diagnosing diseases just from the patient's urine.

Handsch learnt this the hard way. When a sick knife-maker sent his urine, Handsch refused to commit himself to a precise diagnosis. He cautioned his patient that diagnosis just from urine was deceptive. This ended their interaction for the time being. The man sought advice elsewhere. Only months later, he consulted Handsch again, this time in person, for stomach troubles, and he praised an old lay healer he had consulted after Handsch's earlier refusal.

57 Pieter van Foreest, De incerto, fallaci urinarum iudicio (Leiden, 1589); Johannes Hornung, De uroscopia fraudulenta discursus (Herborn, 1611); cf. Michael Stolberg, Uroscopy in Early Modern Europe (Farnham, 2015). 
She had not only explained his illness but had also divined that he was sad about the death of his wife, and that he sometimes had complaints in his loins, both of which were true. The verdict of the old woman, Handsch had to admit, pleased the man ("placuit").58 Like many other physicians of his time, Handsch ultimately not only routinely performed uroscopy but, when he had to, he also offered a diagnosis and recommended a treatment based only on his examination of the patient's urine.

When he examined the urine in the patient's absence and even when he visited a patient in person, Handsch used various strategies that would help him to win the patient's trust and to assert his authority. Some of these strategies are reminiscent of the very tricks and the fraudulent behaviour of which learned medical writers accused their non-academic competitors. The physician, Handsch wrote, should try to find out more about the illness and its possible causes beforehand. When he then entered the sick chamber and appeared to already know what was ailing the patient, it would seem as if he had an almost supernatural, divine knowledge and the patient would trust him more easily.59

Sometimes he even went a step further. He only pretended to examine the urine and resorted to - or invented - a diagnosis that was probable and plausible, no matter what the urine looked like. In the spring, continuous fevers were very common. Therefore, he learnt from his teacher, Ulrich Lehner, he could hardly be mistaken when he diagnosed a fever, ideally adding, when he did not see the patient, that it might be hiding inside the body, in case the patient did not have the typical symptoms. ${ }^{60}$ When he saw or found out that the patient was already elderly, he could confidently proclaim that the patient suffered from fluxes which fell down to the chest, stomach, loins and limbs ${ }^{61}$ or that the patient had a bad stomach and expectorated a lot, especially in the morning. ${ }^{62}$ For it was common knowledge that many elderly patients suffered from such complaints because their vital heat was weakened and their stomach was no longer able to concoct the food sufficiently, producing lots of superfluities. ${ }^{63} \mathrm{He}$ could add that the fluids in the head threatened to provoke a stroke or could make the legs feel heavy when they dripped downwards. ${ }^{64}$ With many patients, he could also hardly be wrong when he claimed that there

\footnotetext{
58 ÖNB, Cod. 11205, 221r.

59 ÖNB, Cod. 11200, 56 r.

6 o ÖNB, Cod. 11205, 25v.

61 Ibid., 424V and 433r.

62 Ibid., 208r.

63 Ibid., 542r.

64 Ibid., 433v.
} 
was an "obstruction," in the liver, the spleen or elsewhere in the body. ${ }^{65}$ Next to "fluxes," "obstructions" were among the most common and widely known diagnoses. People were familiar, Handsch found, with the notion that the lungs, the spleen or the liver could be obstructed, swollen, full of mucus, ulcerous, putrid, or shrunk. ${ }^{66}$ When he examined the urine of a female patient, he could safely diagnose a diseased uterus. ${ }^{67}$ For the uterus was thought to be involved in most diseases of women. So once, when they brought him a urine sample from a place four miles away and only told him it was that of a woman, Handsch, according to his own account, only pretended he examined it. He then offered, in his "customary manner,"68 a diagnosis that was useful with many female patients: the patient had slimy, mucous matter in her uterus, which interfered with her menstruation. Sometimes she also felt heaviness around the loins and in her legs and was hard of breathing. The messenger confirmed everything and only wanted to know whether the lungs or the liver were also affected. ${ }^{69}$

Another major threat to the physician's authority, and to the trust the patients set in him, was the uncertainty of prognosis. Many patients and families demanded a prognosis, if only to make sure spending money on medicines still made sense..$^{70}$ Predicting the future course of a disease, especially when a patient had only just fallen sick, was notoriously tricky, however. For good reasons, some famous physicians like Niccolò Leoniceno and Giovanni Manardi, as Handsch learnt, could hardly ever be pressed to pronounce themselves at all on this point. ${ }^{71}$

In Handsch's notebooks, prognosis - and the serious errors the physician could easily commit in the field - played a very prominent role. That the physician had to refrain from being too audacious in prognosis was a rule of which he repeatedly had to remind himself. It was legitimate and indeed the physician's obligation not to deprive the patients themselves of any hope. Fear and despair might otherwise accelerate the course of the disease. When he talked to the patient's friends and family, however, he had to point out the dangers. ${ }^{72}$ Otherwise, when the physician promised a cure and the patient did not improve, the physician would lose the patient's "trust and esteem". ${ }^{73}$

65 Ibid., 208.

66 Ibid., 435r.

67 Ibid., 208.

68 Ibid., 435r, "dixi solito meo more".

69 Ibid., 435r, "finxi me aspexisse".

70 Ibid., 255v.

71 ÖNB, Cod. 11183, 332v; ÖNB, Cod. 11205, 494r.

72 ÖNB, Cod. 11206, 10ov.

73 ÖNB, Cod. 11205, 410v. 
In actual practice, however, Handsch again and again failed to exercise the necessary caution and had to bear the consequences. The relatives "cursed" him, he had to admit to himself, when a fishery official died in his treatment. He had made the mistake ("meum delictum") to conceal from the wife her husband's serious state, even when she explicitly asked him. ${ }^{74}$ At times, he also made the opposite error and wrongly predicted a fatal outcome. ${ }^{75}$ When a man from the countryside was seriously injured after a bad fall, he told the wife he could not conceal from her that her husband would die. The woman burst into tears but a year later the man was still alive. "Do not be so rash and audacious in your prognosis," Handsch admonished himself once again. ${ }^{76} \mathrm{He}$ fared much better in the case of a 14-year-old girl with a deadly fever. He consoled the patient and her parents and nourished their hopes, but confided to their servant that the girl would die. When the servant told the parents after the girl's death that Handsch had indeed predicted the fatal outcome "they were pleased," he noted. ${ }^{77}$

While there were many pitfalls in prognosis, the astute physician could also turn prognosis to his own advantage, into a means of promoting his standing and his authority. That he should always make the disease sound more serious than it was, when talking to those who assisted the patient (but downplay the dangers towards the patient), was one of Handsch's principles, "for when he recovers, you will receive greater praise [and] when he dies, you will be excused because you have warned of the danger".78 "Pretend that the disease is difficult," he wrote in another entry. ${ }^{79}$ Handsch described how his mentor, the famous botanist and court physician Pietro Andrea Mattioli acted accordingly: "To the bystanders he always makes the disease appear bigger than it is because, he says, this is good for the physicians." 80

Good prognostic skills were also important for a different reason. The best, most convincing means by which a physician could win a good reputation was ultimately the success of his treatment. When word spread that patients got better with the medicines a physician had prescribed, he could expect that

\footnotetext{
74 Ibid., 255v.

75 Ibid., $127 \mathrm{~V}-128 \mathrm{r}$.

76 Ibid., $420 \mathrm{OV}-421 \mathrm{r}$

77 ÖNB, Cod. 11183, 140r.

78 ÖNB, Cod. 11207, 229r, "magnificias semper morbum apud astantes (apud aegrum vero parvifacias), nam si sanatur maior laus tibi erit, si moritur excusatior eris quia monuisti de periculo."

79 ÖNB, Cod. 11205, 212r: "Simula difficilem esse morbum."

80 ÖNB, Cod. 11206, 128v: "D. Matthiolus apud astantes semper pluris facit morbum quam est, quia dicit bonum esse pro medicis."
} 
other, new patients would come to consult him as well. On the downside, this meant that a physician who hoped to establish a profitable practice had to avoid taking care of patients with incurable diseases. Even if he explicitly declared the illness to be incurable, people might still attribute the poor or indeed fatal outcome to his treatment rather than to the disease itself. Accordingly, another motto Handsch highlighted repeatedly in his notebooks was that, in order to protect his reputation, he should follow the example of his teacher Lehner, who made it his "rule" 81 never to accept incurable cases. ${ }^{82}$ This advice was not always easily put into practice, however. Initially, the diagnosis and prognosis were often still uncertain. Handsch recorded cases of patients with consumption and other often fatal chronic diseases, whom other physicians or he himself had started to treat and whom they only left to their fate when their efforts had proved futile. ${ }^{83}$

Sometimes, it should be added, the physicians put the patients' welfare above concerns about their reputation, and would seek to alleviate the patients' suffering even when a cure was no longer possible, by means of a "cura palleativa," as Handsch called it. ${ }^{84}$ According to Handsch's notes, they even took care of clearly moribund patients until the bitter end. Andrea Gallo continued to see a patient, for example, with a massively bloated belly and jaundice who was coughing because of the fluid that had accumulated in his lungs. The night before his death, Gallo still gave him medicine. ${ }^{85}$

\section{Curing Patients}

By the sixteenth century, physicians and lay people alike attributed most diseases to some morbid matter that arose from the insufficient concoction of food in the stomach and the liver, and from processes of corruption and putrefaction inside the body due, above all, to "obstructions" of the natural flow and

81 ÖNB, Cod. 11205, 69ov.

82 ÖNB, Cod. 11200, 126r: "Ne suscipias morbos incurabiles, si famae tuae consultum esse cupis"; similarly, ÖNB, Cod. 11240, 42.

83 E.g. ÖNB, Cod. $11183,82 \mathrm{v}$, on a consumptive woman, whom Handsch continued to treat, at first, when the other physicians had "left" her but then also stopped his visits, about two weeks before her death.

84 ÖNB, Cod. 11240, 36r; on the long history of the concept see Michael Stolberg, A History of Palliative Care 1500-1970: Concepts, Practices and Ethical Challenges (Cham, 2017).

85 ÖNB, Cod. 11207, 7or-70v; for other examples, see ibid., 108-110v, ÖNB, Cod. 11205, 265v and 266r, and ön B, Cod. 11240, 37r. 
excretion of humours. ${ }^{86}$ The principal task of medical treatment was therefore to evacuate the morbid humour that had accumulated in the body. Purgatives and other evacuative medicine that specifically attracted and eliminated the morbid matter were the mainstay of therapy in most diseases. They were frequently supported and complemented by other evacuative methods, such as blood-letting, cupping, enemas or the creation of an oozing ulcer by means of cauterization. Frequently, additional medicines were given to mobilize morbid matter that had settled somewhere in the body and to dissolve obstructions, to strengthen individual organs such as the stomach and the heart, and to fight the harmful effects of the morbid humour in question with medicines that were believed to be endowed with specific "occult" powers against it.

In hindsight, from the perspective of modern medicine, we may have considerable doubts that this kind of treatment benefitted the patients. Published medical observationes, ${ }^{87}$ - whose authors were keen to demonstrate their outstanding therapeutic skills - seldom disclosed any information on bad outcomes for their patients. By contrast, Handsch's notes much more frequently documented fatal outcomes. In such cases, the physician might face heavy criticism, especially when a patient got worse right after taking the medicines the physician had prescribed. People might say things like "the doctor has destroyed him," Handsch noted. ${ }^{88}$ Even when Handsch did not document the family's reaction, we can easily imagine how his treatment was perceived in the case of the sick Frölich, for example, who had fifty stools after a strong purgative was given to him by Handsch, and who then died a few days later; ${ }^{89}$ or in the case of a young nobleman who died after another physician had given him a purgative that provoked thirty stools and made him feel very weak. ${ }^{90}$

Most patients, however, eventually got better; even if only for some time at least, as most patients do regardless of whatever treatment they receive. Acute fevers, which usually only lasted for a few days or a couple of weeks, were particularly rewarding in this respect. Of course, good outcomes were

86 See Stolberg, Gelehrte Medizin, for a detailed account of sixteenth-century disease concepts and a refutation of the still very popular assertion that diseases were, at that time, commonly attributed to an imbalance of the four natural humours and their associated primary qualities in the body.

87 Famous and widely quoted examples were Franciscus Valleriola, Observationum medicinalium libri sex (Lyon, 1573) and the more than thirty books of observations by Pieter van Foreest, Observationum et curationum medicinalium ac chirurgicarum opera omnia (posthumous edition Leiden, 1634).

88 ÖNB, Cod. 11206, 185r.

89 ÖNB, Cod. 11207, 202v.

90 Ibid., 214v. 
generally attributed to the treatment, to the medicines the physician had prescribed, and thereby boosted his reputation. And even when patients did not immediately experience an improvement, the shared belief in the outstanding importance of evacuating morbid matter in order to cure the disease could already strengthen the patients' trust in the physician: their copious evacuations proved that the medicine had the desired effect. The physicians, in turn, did their best to confirm the patients and their families in this belief. The stinking, slimy stools or the vomit their medicines had provoked was offered as visible evidence that they had succeeded in freeing the body of massive amounts of impure, harmful matter that had accumulated inside. Or they showed the blackish fluid with a slimy surface that had collected in the bloodletting bowl as proof of just how necessary and useful it had been to rid the body of this burnt or impure blood. ${ }^{91}$

\section{$7 \quad$ Power}

In common and serious chronic diseases especially, such as consumption, dropsy, gout and kidney- or bladder-stones, the physician had always to expect, nevertheless, that the patients would dismiss him or would at least seek alternative advice elsewhere when the cure did not achieve the desired effect. They had good reasons to do so. There were few general, canonical rules, at the time, for the treatment of different kinds of diseases lege artis. As a result, physicians often came to very different diagnostic conclusions and therapeutic recommendations for the same patient. People knew this from experience. It was therefore always possible that another practitioner would arrive at a different diagnosis and prescribe a different - and more effective - treatment. The physicians nourished this hope in their own way. They stressed their ability to adapt their treatment to the patient's individual bodily constitution and increasingly, with the rise of 'empirical' approaches in learned medicine, they prided themselves on the superior powers of their secret medicines and proven experimenta. ${ }^{92}$

The choices available to patients in the 'medical marketplace' had far-reaching effects on the balance of power in the physician-patient relationship. From the perspective of the physicians, the ideal patient was one who "subordinated"

$91 \quad$ See also Andrew Wear, "Popularized Ideas of Health and Illness in Seventeenth-Century France," Seventeenth Century French Studies, 8 (1986), 229-242, here 238.

92 Stolberg, "Empiricism". 
himself, ${ }^{93}$ who "obeyed". ${ }^{94}$ The patient, as Pietro Andrea Mattioli put it, had to trust the doctor like a helmsman on a ship. ${ }^{95}$ This was wishful thinking, however. Many practicing physicians, Jakob Oetheus in Eichstätt found, complained that patients were not willing to obey and to submit to the physician's orders. ${ }^{96}$

Handsch's notes offer numerous instances of patients questioning or indeed rejecting the physicians' recommendations and prescriptions. They confirm Ronald C. Sawyer's findings for seventeenth-century England that "the patient was not simply the suffering object of a doctor's attention but rather a creative subject actively participating in his or her own disorder." ${ }^{\text {97 }}$ Handsch found, for example, that medical laypersons often refused to accept the physician's advice that a patient who hardly ate anything should take another purgative. There was nothing left in the intestines to clean out, they argued. ${ }^{98}$ The physician then had to try to convince them that the purgative specifically attracted the morbid matter into the intestines. ${ }^{99}$ Some ideas were so deeply rooted in medical lay culture that the physicians found it useless to insist. Female patients, for example, as a rule, categorically refused to take medicines when they were menstruating and paused any treatment they had begun before. They feared that medicines - which usually served to move and evacuate morbid matter - might disturb the natural, health-preserving monthly cleansing of their bodies. ${ }^{100}$

Patients also had a say when it came to the choice of medicines. The physician was well advised, Handsch noted, to avoid medicines with an unpleasant taste. ${ }^{101}$ Some patients had a strong dislike of the sweet medicinal syrups that were widely used at the time and bluntly refused to take them. ${ }^{102}$ Other medicines, like cassia or hiera picra, struck the patients as excessively bitter. ${ }^{103}$ The sick Archduke Ferdinand II once sent immediately for another physician

93 ÖNB, Cod. 11207, 170v: "Submisit se patiens iudicio medico".

94 ÖNB, Cod. 11205, 691r.

95 ÖNB, Cod. 11206, 133r.

96 Jakob Oetheus, Gründtlicher Bericht, Lehr unnd Instruction von rechtem und nutzlichem Brauch der Artzney (Dillingen, 1574), dedicatory epistle.

97 Sawyer, "Friends or Foes," 49; similarly, Weisser, Ill composed, 17.

98 ÖNB, Cod. 11205, 287v.

99 ÖNB, Cod. 11206, 18ov.

100 ÖNB, Cod. 11207, 189v: "Fluentibus menstruis mulieres non accipiunt medicamenta"; similarly, ibid., 221v.

$101 \quad$ Ibid., 1r: "Sis studiosus in exhibendis suavibus medicamentis, scis enim quantum alienati sint patientes ob ingrata pharmaca"; similarly, ÖNB, Cod. 11183, 116v.

102 ÖNB, Cod. 11183, 116r; öNB, Cod. 11205, 147r.

103 ÖNB, Cod. 11205, 410v; Cod. 11207, 209v. 
rather than taking the cassia with hiera picra his personal physician had prescribed. Handsch's mentor and colleague had the same experience with a high-ranking captain. ${ }^{104}$ One of Handsch's patients, he remarked, "loathed" him when he prescribed bitter medicine to her. ${ }^{105}$ On one occasion, Handsch tasted the medicine he had prescribed and he himself found it "disgusting" ("abominabile"). 106

With demanding patients, reconciling the patient's personal preferences with the physician's own ideas and the rationale of his treatment could prove challenging. "Do everything with a good conscience," Handsch admonished himself. He would not neglect the use of necessary medicines or make concessions just to please the patient ("in blandimentum", "propter blanditias"). When strong action was called for, he would be courageous; when it was not indicated, he would say no. ${ }^{107}$ In practice, however, he found it rather difficult to follow these rules. Thus, he allowed a patient to drink cold water, just to please him, even though he knew it would do him no good. ${ }^{108}$ To another patient, with fever and massive shortness of breath, he gave fewer medicines than necessary, just to ingratiate himself. He was rightly despised, he noted, when the patient then died, contrary to his predictions. ${ }^{109}$

Sometimes he also gave medicines just to avoid the impression that he was not doing anything. Thus, he made a sick woman take some rhubarb essence, which was what he happened to have with him. ${ }^{110}$ For a whole week, he treated a patient who was severely afflicted by stones with camomile oil and hiera picra, "more for appearances than following the rules," as he admitted to himself."11

Only in exceptional circumstances would Handsch terminate a course of treatment unilaterally, because a patient proved too rebellious. He left the sick Baron von Meseritz, who "did not want to obey".112 He no longer visited a patient with colics and epileptic fits because he "did not obey and confused everything". ${ }^{113}$ Leaving such patients was in the physician's own interest, even if it meant losing a patient. He could not expect his treatment to bring any

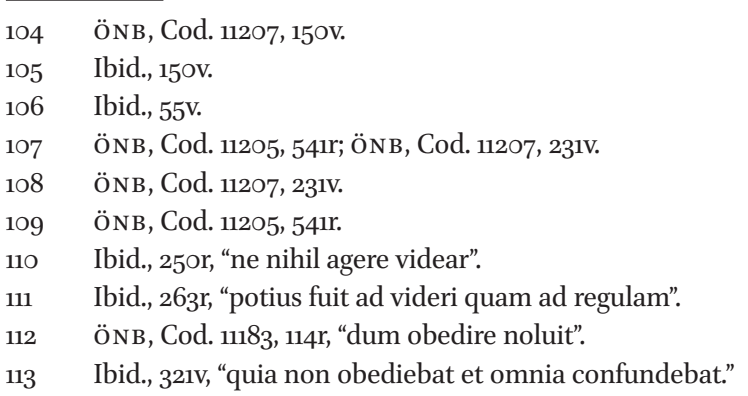


improvement and had to fear that people would attribute the poor outcome to his incompetent treatment rather than to the patient's refusal to follow his advice.

\section{8}

\section{Money}

A final important source of potential conflict were the physicians' financial demands and expectations. In order to grasp the importance and impact of the economic aspects of the physician-patient relationship, we have to keep in mind that enriching oneself at the expense of others was considered far more offensive in the sixteenth century than today. The moral indignation was not limited to lending money against interest. Work on the history of accounting has shown that even the rich merchants in the prosperous trading cities felt the need to justify before God the profits they made by selling goods for a higher price than they themselves had paid. In an attempt to reconcile their profits with their faith, they added religious symbols and prayers to the figures in their account books. ${ }^{114}$ The income a physician earned from treating patients was even more reprehensible when seen from this perspective. He fattened his pockets from the suffering of his fellow human beings. Worse still, he earned all the more, the longer it took him to heal the patient - quite possibly due to his own incompetence or even as a result of his deliberately prolonging the treatment.

One of the major successes that academic physicians achieved in a longterm process of professionalization was in convincing patients, governments and society as a whole that their services deserved to be compensated for the effort they made, no matter whether they were successful or not. Medical writers in the Renaissance still battled to get this message across. When the physician was unable to cure a patient but had done everything that was in his power, he still fulfilled his tasks perfectly, Orazio Augenio argued. ${ }^{115}$ Others pointed out that lawyers also had to be paid, whether they won their cases or not. 116

The physicians frequently complained about their patients' ingratitude. Handsch was no exception. After eight years as a physician in Prague,

\footnotetext{
114 James Aho, Confession and Bookkeeping: The Religious, Moral, and Rhetorical Roots of Modern Accounting (Albany, NY, 2005).

115 Orazio Augenio, Epistolarum et consultationum medicinalium prioris tomi libri XII (Venice, $1602), 88 \mathrm{v}$.

116 Ludwig von Hörnigk, Politia medica (Frankfurt am Main, 1636), 7.
} 
he declared he was sick of the "minuscule and debasing remuneration" he received from his patients, which hardly sufficed for food and decent clothing. ${ }^{117}$ According to Handsch, some patients did not pay at all. ${ }^{118}$ Philipp Bech in Basel even claimed that only every twentieth patient rewarded him for his efforts. ${ }^{119}$ This was undoubtedly either a massive exaggeration or Bech was unusually inept. After all, many physicians earnt a good income from their practice. In 1573, when he had only just settled down in Zwickau, Hiob Finzel, for example, already received about 350 gulden from his patients - almost six times his salary as a town physician - and a few years later, in 1579, he reached a peak with more than 500 gulden. ${ }^{120}$ That physicians had to wait for fees and sometimes never received them, seems to have been a fairly common experience, however. Bäris in Schlettstadt found that he could not insist that patients pay their outstanding fees. He was still fairly new in town and worried that they would prefer other physicians if he pursued payment too insistently. ${ }^{121}$ Euricius Cordus in Braunschweig mentioned 30 gulden still owed to him by patients he had successfully cured (but did not suggest that he no longer expected to receive that money). ${ }^{122}$

As much as the physicians insisted that their services were ultimately priceless, many patients seem to have regarded them not as fundamentally different from those of members of other trades (whom they also might not pay right away). The terms commonly used in this context are revealing. The physician - like other medical practitioners - did not receive an "honorarium," but "merces," derived from the Latin word "merx" for goods, a "lucrum" or a "praemium". 123

This was more than just a semantic question. When the treatment did not have the desired effect, some patients, at least, felt that the physician had not fulfilled his part of the deal and was not entitled to a generous reward or indeed payment of any kind. Patients could find their attitude confirmed by

117 Cod. 965o, 76v-78r, a copy of a letter from Handsch to Pietro Andrea Mattioli, 26 April 1561.

118 ÖNB, Cod. 11206, 183r.

119 Letter from Bech to Joachim Camerarius the Elder, Basel, 13July 1556 (Universitätsbibliothek Erlangen, Trew, Bech, Nr. 4; summary online at www.aerztebriefe.de/id/ooooo175, last accessed 8 January 2021).

120 Stolberg, "Sixteenth-Century Physician," table 1.

121 Letter to Bonifaz Amerbach, 23 July, 1555, ed. Jenny, Amerbachkorrespondenz, 626-627; summary online at www.aerztebriefe.de/id/oooo8211, last accessed 8 January 2021.

122 Letter from Euricius Cordus to Johann Lang, Braunschweig, 24 June 1524 (Universitätsbibliothek Erlangen, Trew, E. Cordus, Nr. 3; summary online at www. aerztebriefe.de/id/ooooo518, last accessed 8 January 2021).

123 See, e.g., Zerbi, Opus perutile, chapter on "De mercede medici accipienda"; Handsch also used the term "praemium" (e.g., ÖNB, Cod. 11205, 312v and 573v). 
non-academic practitioners. According to Handsch's notes, barber-surgeons and lay-healers sometimes even made a pactum, a healing contract. ${ }^{124}$ They agreed that their efforts would be compensated depending on their success. For example, a barber-surgeon who treated a patient with a painful ulcer was to receive altogether three taler for his efforts, one when he began the treatment, the second when the ulcer had improved, and the third when it was healed. ${ }^{125}$

The learned physicians considered such contracts as a danger to their dignity. "The physician must not negotiate with the patient," Ludwig von Hörnigk admonished his readers. ${ }^{126}$ Handsch wrote down words he could use to reject such propositions, i.e., "when they want to make a contract". ${ }^{127}$ Even when there was no formal contract, letters from patients and their families indicate, however, that the sick felt that the physician deserved a more generous payment when his treatment was successful, and therefore implicitly a less generous one when the treatment was to no avail. ${ }^{128}$ The same notion transpires from Handsch's indignation about certain patients, who got healthy again but pretended they were still sick, "in order to give little or nothing to the doctor". ${ }^{29}$ According to Handsch, some patients (or heirs) even refused to pay their debts with the pharmacists for the medicines the physician had prescribed in vain. ${ }^{130}$

\section{$9 \quad$ Conclusion}

It is a rich and varied picture of the physician-patient relationship that emerges from practice journals, physicians' personal notes and similar sources that reflect everyday medical practice in the sixteenth century. In the case of

\footnotetext{
124 Such pacts or healing contracts are already documented for the High and Late Middle Ages; see Joseph Shatzmiller, "Doctor's Fees and Their Medical Responsibility. Evidence from Notarial and Court Records," in Paolo Brezzi and Egmont Lee, eds., Sources of Social History. Private Acts in the Late Middle Ages (Toronto-Rome, 1984), 201-208. ÖNB, Cod. 11205, 245v; ibid., 267v, on a "pactum" between a Jewish healer and a paralyzed nobleman.

126 Hörnigk, Politia medica, 7.

127 ÖNB, Cod. 11205, 215v: "Si volunt pactum facere"; ibid., 291r, "si volunt facere pactum ante curationem".

128 The patients who turned to the Brandenburg court physician Leonhard Thurneysser for epistolary advice, in the 1570 s and 158 os, usually sending also their urine, often promised to show their gratitude in monetary terms if he was able to cure them (Staatsbibliothek Berlin, Mss. germ. fol. 99, 420a, 42ob, 421a, 422b, 423a, 423b, 424, 425 and 426). ÖNB, Cod. 11205, 676v.

130 Ibid.
} 
many lower-class and rural patients, the relationship was limited to a one-off encounter and the physician did not even bother to record - and maybe not even ask for - the patient's name. With others, usually more educated and affluent patients, he established a long-standing relationship. The personal physicians of kings and princes might even enjoy the kind of privileged access to the ruler that many members of the aristocracy sought in vain.

The balance of power in the physician-patient relationship was, in many respects, tipped in favour of the patients. The physicians were constantly faced with the possibility and threat that the patient would turn to someone else. In contrast to modern medicine, where patients are unlikely to get a totally different diagnosis and treatment when they consult another practitioner, the patients had a very real choice. Another practitioner was more than likely to recommend a different treatment and to prescribe different medicines. To what degree the patients' relatively powerful position was, in hindsight, to the patients' benefit is quite a different matter. The possibility of consulting someone else who was likely to arrive at very different diagnostic and therapeutic conclusions gave patients an empowering choice that patients today rarely enjoy. However, it also nourished a profound sense of insecurity. After all, when two physicians disagreed, the patients often had no means to decide whom they could trust.

Even the pressure on the physicians to cultivate good bedside-manners, to accommodate the patients' personal preferences and to win their confidence came at a price. As we have seen, it could promote behaviours on the physician's part that we would consider as highly reprehensible and immoral today. Fearing for their own reputation, physicians left incurable and dying patients to their fate. Some physicians, like the famous Mattioli, systematically exaggerated the dangers of the disease in question, in order to make their treatment seem all the more valuable - and worthy of a generous fee - when patients recovered, while they avoided blame when the illness took an unexpectedly negative course. Handsch sometimes did not even attempt to uncover the true nature of a patient's disease and simply pronounced a diagnosis that seemed probable and plausible, given the patient's age, sex, and the time of year.

On the other hand, one of the most striking positive features that emerges in particular from Handsch's notes, was the degree to which physicians were prepared - or felt compelled - to explain to the patients what precisely was happening in their bodies, in a way that they could understand and that made sense to them. Learned medicine may not have been efficacious, and may indeed often have been harmful, according to the standards of modern 
medicine. But it was of the utmost importance as a source of orientation, resilience, and empowerment in the face of the constant threat of dangerous and deadly diseases. From the patients' perspective, the frequency of positive outcomes was enough to confirm and justify their trust, at least in learned medicine per se, if not in the individual physician. 